\title{
Social Impact of Industrialization Policies on Fishing Communities in the Outer Islands: Case of Natuna, Indonesia
}

\author{
Hertria Maharani Putri \\ Regional and Rural Planning Research Group, School of \\ Architecture, Planning and Policy Development, Institut Teknologi \\ Bandung, Indonesia \\ hertria.maharani@gmail.com
}

\section{Delik Hudalah}

School of Architecture, Planning and Policy Development, Institut Teknologi Bandung, Indonesia

\author{
Wilmar Salim \\ Research Center for Infrastructure and Regional Development and \\ School of Architecture, Planning and Policy Development, Institut \\ Teknologi Bandung, Indonesia
}

Publication Information:

Received 18 April 2021, Accepted 9 May 2021, Available online 29 June 2021

DOI: 10.21463/jmic.2021.10.1.13

\section{Abstract}

Natuna Island is one of the outer islands in Indonesia with under-development conditions due to its remote location. The government initiated to build fisheries industrialization and turning them into a growth center. So far, it is considered to only have affected their economic life. In fact, it also impacted the social life of their local community. However, differences in the characteristics of the people on small islands which are different from those on the main islands, may result in the destruction of endogenous social relations of the community by the industrialization process. This paper identifies the impact of exogenous development in the form of fisheries industrialization on the social life of the fisherman using the Social Impact Analysis (SIA) method. Sources of data were obtained from FGD with stakeholders, indepth and semi-structured interviews, content analysis of related documents, as well as observations. From the study results, it is evident that there have been several negative impacts on fishing community due to fisheries industrialization. This impact results in the loss of social strength in the form of access to marine production bases. Local fishermen are driven out of their own sea areas, in the sense that their fishing grounds are used by other fishermen so that they have to change fishing locations. Second, there is no development of political power in the form of individual access to making decisions, voicing aspirations, and acting as a group because the established institution is only used as a formality to get assistance. Finally, fishermen's self-confidence has decreased because they continue to feel 
unsupported. The increasing number of new players in the sea area often adds to the fishermen's sense of inferiority. These changes seem to discourage the local community from supporting the implementation of the government development programs.

\section{Keywords}

Social Impact, Outer Islands, Natuna, Fisheries industrialization, Fishing community

\section{Introduction}

The development of outer islands or small border islands has begun to be widely discussed in development theory literatures. In the core-periphery model, small border islands can be categorized as a resource frontier region due to their remote location and great potential of resources waiting to be transformed into alternative development areas (Friedmann, 1966; Roeseler and Azam, 1990). The outer island development is carried out by attracting numerous investors and building massive infrastructure. If fisheries the primary reliable sector, it will be industrialized by boosting the huge production (Thanoon et al, 2003) and altering the infrastructure (Abdullah et al, 2009). This approach still follows the conventional pattern that focuses on economic growth with an emphasis on the role of the state in providing economic assistance (Selwyn, 2011; Clark, 2009). The purpose of this development is to increase opportunities to improve the welfare of the islanders. The government builds infrastructure such as roads, dams, airports and port facilities to integrate remote areas into wider socio-economic activities for easier accessibility (Persoon and Simarmata, 2015).

Natuna Islands is one of the outer island developments which carried out by attracting numerous investors and building massive infrastructure. This can be seen from the programs that are taking place in Natuna, such as the development of a fishery-based area by forming a city on the island which is often referred as the Minapolitan program in 2010 and The Integrated Marine and Fisheries Center (SKPT) which was initiated in 2015 (Bappeda Kabupaten Natuna, 2015). In accordance with the Regulation of the Minister of Marine Affairs and Fisheries of the Republic of Indonesia Number PER.12/MEN/2010 concerning Minapolitan, Minapolitan is a part of the region that has the main function of the economy consisting of production centers, processing, marketing of fishery commodities, services, and / or other supporting activities. The existence of regional development is expected to be able to improve the economy of the people around the area (KKP, 2012). Meanwhile, the SKPT is the central government's program to build a center for fish landing before being distributed to various market destinations. Both programs are exogenous and focus on infrastructure development, which is the priority of the central government, especially the Jokowi administration (Salim and Negara, 2019).

Development by creating growth centers and modernization is common in urban areas or hinterland areas close to core areas. Industrialization in small island is still very uncommon, and its application will certainly have a different impact compared to if it is carried out in the mainland. Apart from the difference in spatial conditions, small island communities also have different characteristics from those in the mainland. For indigenous people or islanders, their social life is a way of life that they have maintained for generations. As it is a small place, all events on the island, both externally or internally, will interrelate and may affect the vulnerability of the island (Lewis, 2009). Islanders tend to preserve their traditions and their way of thinking, having their own way of socializing that tends to be secluded from the outside world. 
Social relations of a traditional society tend to create resilience against incoming external influences (Tomkins and Adger, 2004). This will be very different from the opinion that modernization may occur when the society begin to abandon their traditional values (Sofield, 2003).

Industrialization and modernization are expected to increase stakeholder participation because they involve the roles of the central government, investors and new markets and it will create change in their social relations. The stakeholder involvement can change the co-management pattern of the island's natural resources. However, it may increase the potential for conflict (Pomeroy and Berkes, 1997; Torre-Castro, 2006). Whereas island communities, especially fishermen, have already had a strong patron-client relationship (Aida, Agustang, A, Adam and Agustang, AD, 2020)

This conflicting view between industrialization and endogenous social relations issues, reflect on several major opinions in literatures. The first group of literature argue that industrialization may increase the economic growth and contribute to the development of social relation (Putnam, 1993:180). Industrialization also causes social change that continually increases society's capacity to produce a wide range of goods (Hewitt et al. 1992: p.3-6). Meanwhile, the second group views that industrialization contributes to the decline of the longstanding social and moral ties which bound communities together (Ciscel and Heath, 2001). In addition, industrialization can destroy existing social relations as much as social relations can hinder the success of industrialization itself (Sobel, 2002; Miguel, 2006).

Exogenous development and the hope of increasing community participation and strengthening social relations also occur on Natuna Island. The government tries to build the outer islands with various forms of exogenous development but often the government overlooks the social impacts that will occur on the island community when it is done. The objectives of this paper are, therefore: to describe the social impacts of industrialization of fisheries on Natuna; to explain the effect of the social impacts on the Natuna fishing community; and to propose assessing Islanders' Rights as one of the important component in island development sustainability which is arguably missing in the current literature. From the results of these objectives can be seen a better understanding on these conflicting views on industrialization and social relation in island context. The fisheries industrialization will not only affect the economic life of a community, but also might destruct the social relations of the remote islanders, in this case the fishing community. Social impact has the same degree of urgency as the economic impact generated by a policy; therefore, it is necessary to carry out an analysis of the social impacts that occur on the islanders, particularly the fishing community, due to the massive development from the central government.

\section{Methodology}

In island case, social relations could not be captured by a quantitative approach that emphasizes in income and other material values as a quantification of an area's underdevelopment (Grydehøj \& Hayward, 2014). To meet the objectives, this study applied qualitative approach using Social Impact Analysis (SIA) as a tool to assess the social and cultural impacts of industrial activities on indigenous people and whether it can increase the positive impact on society (Esteves, 2008; João et al. 2011). Social impact can be defined as all the social and cultural consequences on the human population from any public or private action that changes the way people live, work, interact with others, organize to meet their needs, and generally cope as members of society (Burdge and Vanclay, 1996). There are at least 4 stages in SIA: identifying the local context; understanding the capacities and perceptions of the local community; involving the role of the community; and empowering the community (Vanclay, 2015). In this article we shall identify problems that exist in 
the local context; and the capacities, perceptions, and social consequences, be it intentional or unintentional, bearing positive or negative impact, of planned interventions (policies, programs, plans, projects) and any process of social change caused by those interventions (Vanclay, 2003). SIA is used to ensure that the development (or planned intervention) maximizes the benefits and minimizes the costs of the development, especially the costs borne by the community.

There are 2 steps that are taken in the social impact analysis for this study. First, determine the problem that led to social impact. At the initial stage, the researcher conducted an interview individually and then clarified the data obtained through the FGD. At this stage an FGD is conducted with the stakeholders. The topics of FGD are the latest conditions on fisheries industrialization and problems or obstacles during the program implementation process. The informants invited to the FGD were staffs of the Fisheries Office of Natuna Regency and fisheries extension agents because their understanding of the characteristics of the community and the program they are implementing. Also invited were staffs of Fisheries Service of Kepulauan Riau Province as an extension of the central government, the SKPT coordinator as the implementor of the program, and the chairman of the Natuna branch of the Indonesian Fishermen's Association as a representative of the community. In this FGD, data analysis was carried out by analyzing each question that was asked, to look for similarities in the theme, and then looking for consensus and conflicting opinions and making comparisons between the invited groups. The results of the FGD, are the main material or issues that will be asked or confirmed in indepth interviews. Beside the in-depth interviews, interviews were also conducted using a questionnaire to obtain basic data such as the number of days at sea, or the fishermen's fisheries supply chain which will be used as supporting data for social change in the community.

Second, determine any kind of transformation that might occur resulting from the problems. Social impact can be observed from several indicators, including the emergence of community awareness, social cohesion, equitable distribution of income, quality of life and level of happiness (Bostrom, 2012); social relations and high levels of community participation (Dempsey, 2011); community empowerment and participation in decision making (Bridger, 2006). In this article it can be concluded that the social impacts of a program can create at least 4 transformations in society, including: 1) Community awareness; 2) Cohesion and the formation of social relations between communities; 3 ) Participation in internal and external decision making; 4) Equitable distribution of income, quality of life and level of happiness. These 4 indicators shall be the object of the SIA approach in observing the social impact of industrialization policies on the fishing community.

Table 1. Steps used in the SIA Process

\begin{tabular}{|l|l|}
\hline \multicolumn{1}{|c|}{ Step 1: Identifying Problems in local context } & \multicolumn{1}{c|}{ Step 2: Identifying any process of Social Change } \\
\hline Purpose: Determine the problem that led to social impact & Purpose: Determine any kind of transformation, social change \\
\hline $\begin{array}{l}\text { Through: FGD with stakeholders (Fisheries Agencies, Program (SKPT) } \\
\text { implementors, Fisheries Local Community), in-depth interview (with note } \\
\text { and questionnaire - 57 persons), and observations. }\end{array}$ & $\begin{array}{l}\text { Through: FGD with stakeholders (Fisheries Agencies, Program (SKPT) } \\
\text { implementors, Fisheries Local Community), in-depth interview, and } \\
\text { observations. }\end{array}$ \\
\hline
\end{tabular}

The occurring social impacts are the result of the implementation of government programs in the development of Integrated Marine and Fisheries Centers (SKPT) in accordance with the Ministerial Decree Number 40/PERMEN-KP/2016 concerning the Assignment to Implement the Development of Integrated Marine and Fisheries Centers in Small Islands and Border Areas. The SKPT Natuna is the central government's program to build a center for fish landing before being distributed to various market destinations such as Batam, Tanjung Pinang, Pontianak and Jakarta. This integrated 
fisheries center is located in the south of Natuna Island, Selat Lampa (see Figure 1). In this second stage, data collection has been carried out through Focus Group Discussion/FGD (by collecting public opinion on the fisheries industrialization being built) and in-depth interviews to obtain primary data with fishermen on Pulau Tiga (5 key informants) and Pulau Sedanau (4 key informants). In the FGD, questions were related to 4 forms of social transformation 1) Community awareness; 2) Cohesion and the formation of social relations between communities; 3) Participation in internal and external decision making; and 4) Equitable distribution of income, quality of life and level of happiness. Secondary data have been obtained from regulations, documents, journals, and reports related to regional developments in the outer islands. The case study was conducted in Natuna Regency, Riau Islands Province, which took place from August to November 2020.

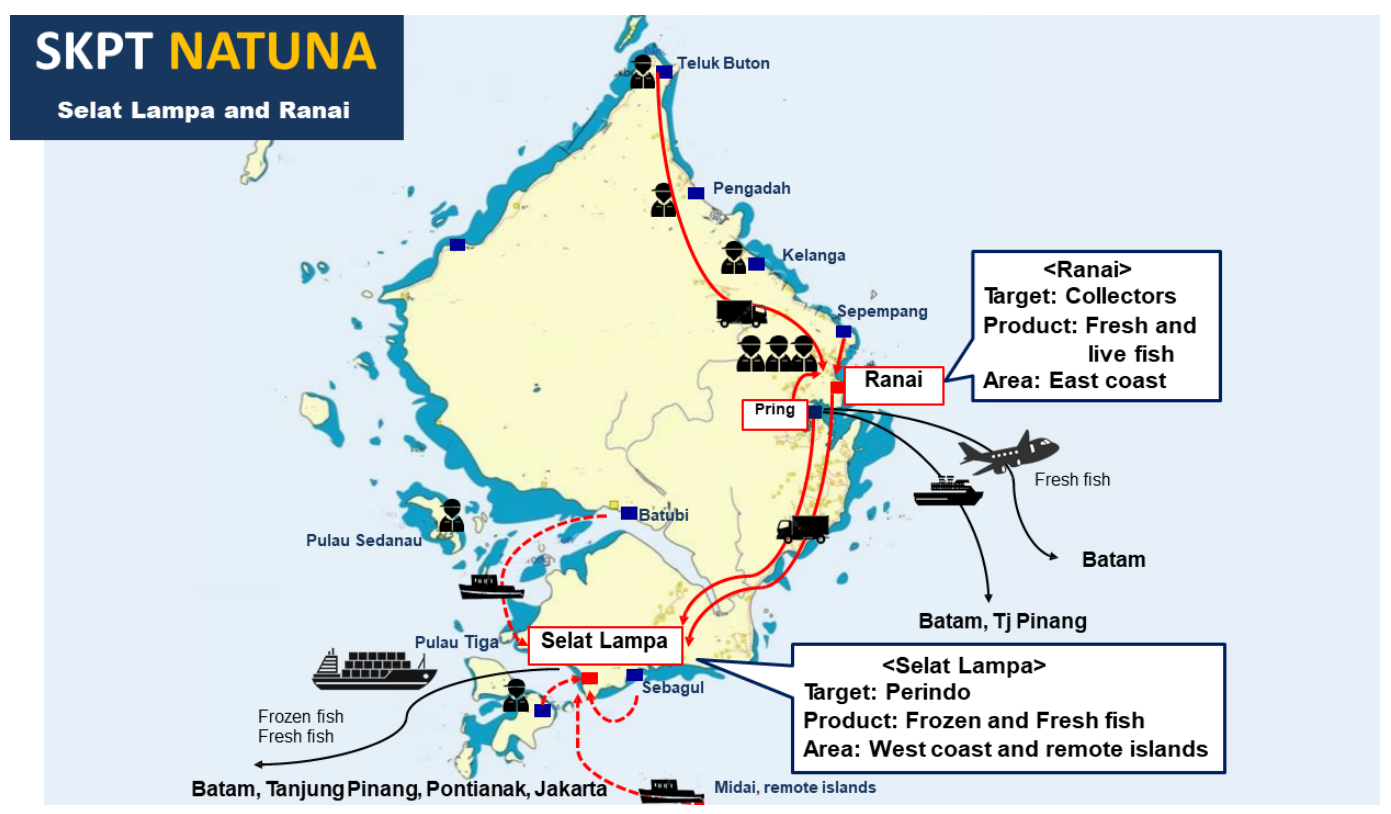

Fig 1. The Flow of Fish Marketing in The SKPT Natuna Scheme [Source: (Kementerian Kelautan dan Perikanan, 2017)]

Natuna is a small island that continues to grow, and this can be seen from the increasing population. In 2015, at least 74.5 thousand people lived in Natuna Regency, in 2018 the population increased to 77 thousand people and in 2020 the population has reached 81 thousand people (BPS, 2021). About $27.3 \%$ of the peoples in the Natuna Islands depend on jobs in the fisheries sector. The majority of the population depends on the capture fisheries business. The largest number of Natuna fishermen are around Bunguran, Natuna Besar, Pulau Tiga, Midai, and Pulau Serasan. In Natuna, the largest share of GRDP was controlled by the gas and oil sector by $75 \%$ in 2015 . Although, the share of the agricultural sector including the fisheries and forestry sectors was still very low (less than $10 \%$ ) the role of the fisheries sector is very dominant (more than 40\%) if the oil and gas sector is excluded (BPS Kabupaten Natuna, 2017). This shows that the fisheries sector can be an important sector in the development of Natuna Regency.

SIA is a tool to assess the economic, social, and cultural impacts of industrial activities on a community, including those in a remote island. It is particularly relevant for extractive industries, whose activities often encroach on the land and waters on which the islanders depend on their traditional livelihood activities. This analysis shall identify the potential impacts on the resource use areas of the islanders (Burdge \& Vanclay, 1996). By doing so, this analysis shall help to 
avoid potential negative impacts on natural resources or forms of resource management that they have been carrying out for generations. Policymakers will be able to predict changes that occur in the local community, such as fear, anxiety and distrust of programs that will certainly affect the attachment to the place, social capital, and community welfare which are the goals of creating development in an area (Vanclay, 2015). If the program fails to appropriately address social impact issues, it will reduce support from the local community to implement or run certain programs and will potentially lead to serious financial setbacks for investors (Franks et al. 2014).

\section{Conceptual Framework on Industrialization and its Social Impact}

Industrialization is expected to become the solutions to develop activities in other areas of community life and expected to increase production and national income (Sutikno \& Suliswanto, 2017). Industrial development create competitive economic performance through income and employment, facilitates international trade and increases resource efficiency, and is thus a major driver of poverty alleviation and shared prosperity. For developing economies, industrialization implies structural transformation of the economy from traditional sectors such as agriculture and fishery to modern manufacturing (UNIDO, 2020).

Industrial development will create economic growth and encourage social engagement in the development process. According to Putnam (1993), economic growth will foster the engagement of local communities and this involvement will encourage economic growth. Social engagement will increase the human capital of an area while economic development will encourage prosperity. Prosperity and human capital are the expected results of industrialization. Through enhancing social engagement, will emerge norms and beliefs to promote economic growth, as well as increasing the dense of social relation that will help maintain such norms (Putnam, 2000). Thus, economic development and social development grow together to improve human welfare and capacity in realizing a competitive regional economy. This pattern will occur if there is a cooperation between local people and bussines (Putnam, 1993). The shared understandings, tacit rules, agreed procedures, and social trust generated by personal contact and the bonds of friendships are believed to make it easier for people to work together in the future for mutual benefit (Norris, 2001).

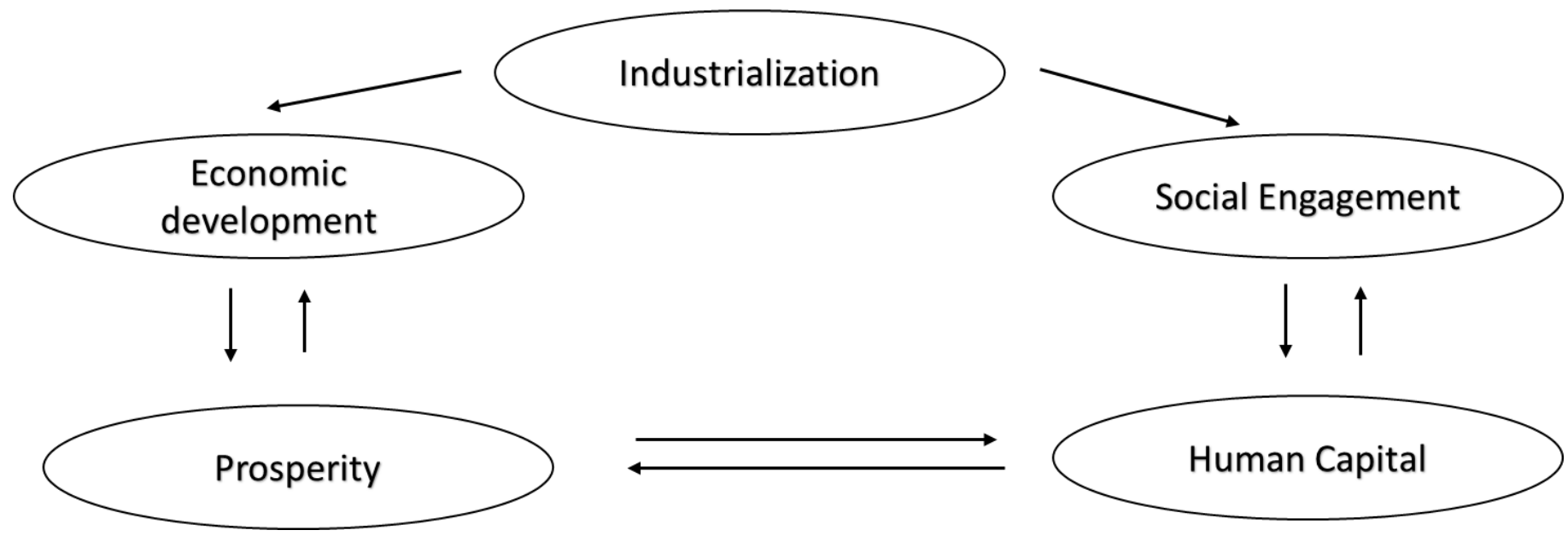

Fig 2. Conceptual Framework on Industrialization and Its Impact [Source: (Adopted from Putnam, 1993)] 
But on other hand, there is a thought that says that strong social relations are contrary to economic activities initiated by actors outside the region. Traditional social networks and norms might discourage the adoption of unfamiliar and unconventional new technologies and economic activities, further stifling growth (Akerlof, 1976). Industrialization is seen as a threat to cultural autonomy and indigenous cultural practices (Smith et al., 2000). Modernization, new cultural flows, and market forces are major threats to indigenous cultural norms, beliefs and practices and institutional mechanisms (Kala, 2011). Industrialization which is the period of social-economic transformation from agrarian or any primary activities into industrial society will reorganizes the society (O'Sullivan, 2003). This idea is in line with the assumption that industrialization will break down the social and moral networks that unite society and can even hinder the process of economic growth in the region itself (Ciscel and Heath, 2001; Miguel 2006).

Industrialization might hinder the economic growth because it is creating the disruption of social structure, social pattern, and the emergence of new political distribution as well as new social classes. This might determine the local community's support on the program implementation. Understanding the local community's inherent rights on the island is an integral part in planning. Furthermore, assigning roles to the local community is the key to obtain a program design that corresponds with local knowledge thus increasing support for development programs and ensuring program sustainability (Bamberger, M 1986; Castles, S 2001). So, industrialization development does not automatically increase the social role of society, but industrialization can destroy existing social networks. The damage to these social networks will create backfire effect in the process of improving the local community's economy.

\section{Results}

\section{Fisheries Industrialization on Natuna Islands}

Industrialization is usually carried out in areas that have complete development potential from upstream to downstream. These areas are often referred to as core regions. The areas outside those regions are called periphery areas, which are usually tasked with supporting the implementation of industrialization that develops in the core region. There are several reasons to not develop periphery areas into growth centers. Among them are because growth centers require human and spatial resources, such as quality institutions and governance (Krugman, 1991); locations that allow overflow of localized technology (Baldwin and Martin, 2004); institutions, including both central and local government, education centers, business support centers (companies, incubators, technology parks); adequate transportation to facilitate accessibility (Gren, 2003), as well as the existence of regional and local business groups (Cooke et al., 2004).

However, there has been a shift in the development concept from being much centered on core towards peripheral areas. The central government, as the country's representative, felt that it must play a big role in encouraging growth centers in periphery areas, including those in the remote areas. Indonesia had desired to conduct development starting from the periphery areas based on its President's directive in Nawa Cita. Development from the periphery areas is expected to help reach the minimum threshold for the density level of productive activities in an area, so that there will be a competitive surplus of production to be supplied to other regions. This will be supported by the development of basic infrastructure that encourages inter-regional connectivity, namely the development of transportation infrastructure (Priyarsono, 2017). One of the periphery areas referred to in the President's directive is the outer islands. The small islands in the border area are known to be vulnerable and have special challenges such as their isolated state, sensitive environment, high 
dependence on seasonal activities and external inputs, demographic imbalances, and insufficient public infrastructure (Baldacchino and Pleijel, 2010). Therefore, it is necessary for the central government to have a big role to create growth centers in such region.

The government has tried to increase development in the outer islands by introducing extractive industries such as fisheries, which have great potential on the island. The aforementioned fisheries industry shall present a supply chain from production to consumption for certain types of fish in accordance with market needs (Kent, 1986). Based on the Decree of the Minister of Fisheries and Marine Affairs (KKP) Number 48 of 2015 and Presidential Instruction Number 7 of 2016 concerning the Acceleration of the Development of the National Fisheries Industry, an Integrated Marine and Fisheries Center (SKPT) was formed as development of a fisheries business system, for provision of fishes for consumption for food security, local economic growth, and community income as well as to increase exports of fishery products. SKPT aims to build and integrate marine and fisheries business processes by developing integrated marine and fisheries infrastructure; forming capable human resources and institutions; developing partnerships to support and strengthen the implementation of the production chain of the marine and fisheries business; provide guidance, assistance and supervision of the implementation of the marine and fisheries business for the people in small islands and border areas.

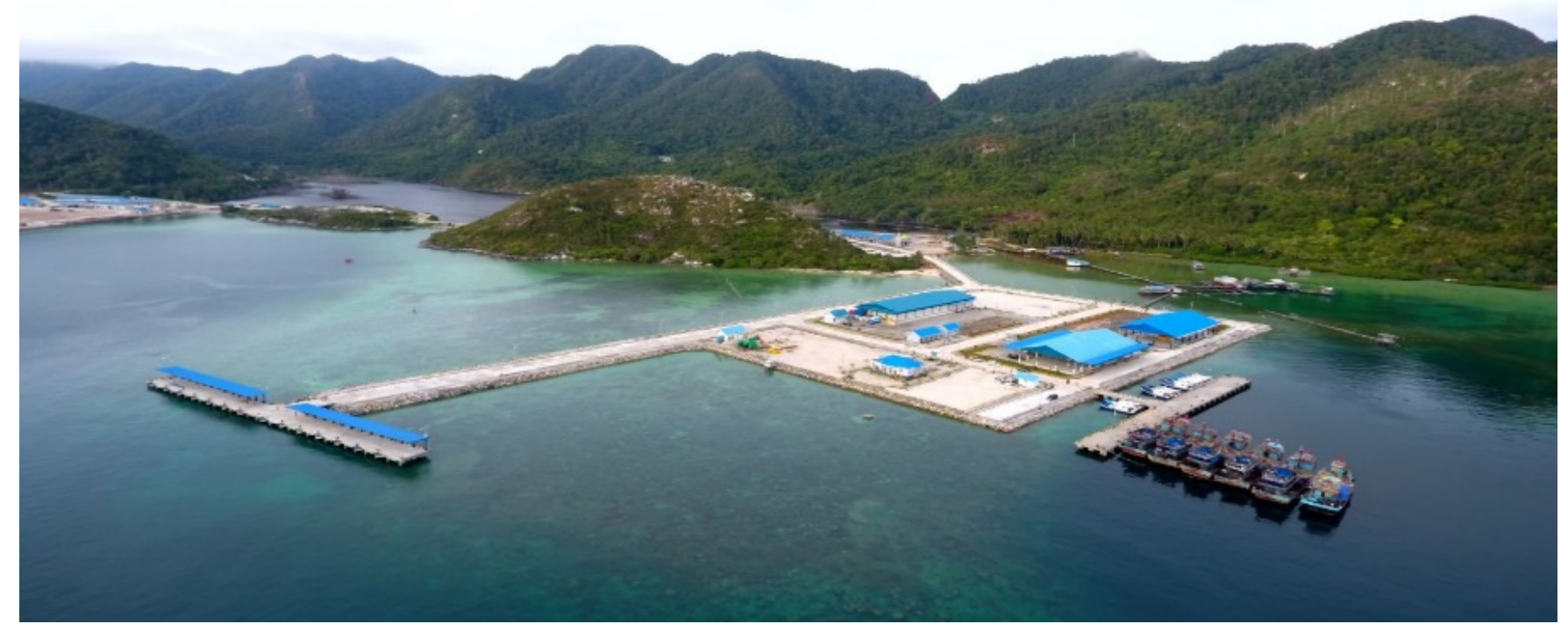

Fig 3. Integrated Marine and Fisheries Center (SKPT) Fishery Port in Natuna Regency [Source: KKP Planning Bureau, 2017]

The SKPT Natuna (see Figure 3) which was built in Selat Lampa (southern part of Natuna) emphasizes infrastructure development such as a dock for berths for vessels below and above $30 \mathrm{GT}$, as well as a number of other complementary facilities such as fish marketing point, integrated cold storage (ICS) with a capacity of 200 tons, fuel oil kiosk, clean water treatment plant, net repairing area, and sailing supplies kiosk. Business operationalization is handled by BUMN Perindo (Indonesian Fisheries Corporation) who has invested in cold storage (DJPT, 2017). Since Perindo started its operation, the expected business cycle is that fishermen will be given capital loan to sail by Perindo, and the fishermen will later deposit their catch to a company located in the port of Selat Lampa. The sailing capital includes fuel supplies (BBM) and 
ice to preserve fishes while on board. Such capital is only provided for fishermen in groups who are members of cooperatives. In addition to that, the central government strengthens the upstream sector by moving ex-North Coast of Java trawler fishermen (the "ex-trawlers") to the waters of Natuna EEZ to catch fish, and to land their catches at Selat Lampa. Local fishermen will also receive knowledge to be able to sail in the EEZ and receive ships over $150 \mathrm{GT}$ from the KKP. With the establishment of facilities, an integrated upstream sector with abundant fish production, and an integrated downstream sector, Natuna Regency is considered to turn into a new fisheries-based regional growth center.

The changes brought by the establishment of the SKPT have caused several problems on the field. These problems can be divided into 2 categories: the problems in the upstream side and the downstream side. In the upstream side, the main problem comes from the change of fish landing sites from local landing sites to Selat Lampa. Selat Lampa is located at the southern tip of Natuna Regency. Meanwhile, Natuna Regency consists of numerous small islands with differing distances to Selat Lampa. The significantly long distance from their island of origin incurs additional costs and time for the fishermen when they must get fuel and ice from Selat Lampa. According to the interview with fishermen of Pulau Tiga and Pulau Sedanau, $85 \%$ of local Natuna fishermen are ship owners who bear their own operating costs. In addition to that, not all fishermen have access to the fuel and ice that they need to sail. This happened because of the limited capacity, and that Perindo has already affiliated with certain fishermen groups under its guidance. As the result, many new fishermen groups have emerged to access the facilities that are provided by Perindo as SKPT business operator.

Another problem is related to the emergence of the ex-trawlers in Natuna waters. It turned out that the trawls they used were not suitable with the currents of the Natuna EEZ waters. The incompatibility of fishing equipment and the water currents caused the ex-trawlers to migrate and fish in the territorial sea, below 12 miles from the coastline. As a result, the fishing areas for local fishermen and migrant fishermen became mixed. In interviews with the fishermen of Pulau Tiga, they stated that their catch had decreased by $50 \%$, and they had to sail further if they wanted to catch a lot more fish. Before the appearance of ex-trawlers, it was already enough for them to fish around the coastline. Because of this, the fishermen can only work to support their daily life without being able to save money. Migrant fishermen with trawling technology got a higher catch, while local fishermen using hand line fishing gears caught less. In fact, it is not uncommon for local fishermen to have to sail farther to get more fish. Local fishermen who previously only need to sail under 12 miles now started to sail up to 70-100 miles. They no longer took 1 working day to sail, but 3-6 working days. These changes will certainly affect the operational costs of sailing such as fuel, ice and rations or foodstuffs while on board (see Figure 4).

$100 \%$

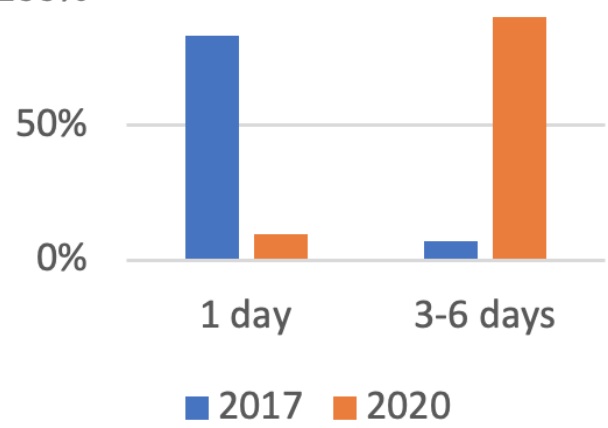

$100 \%$

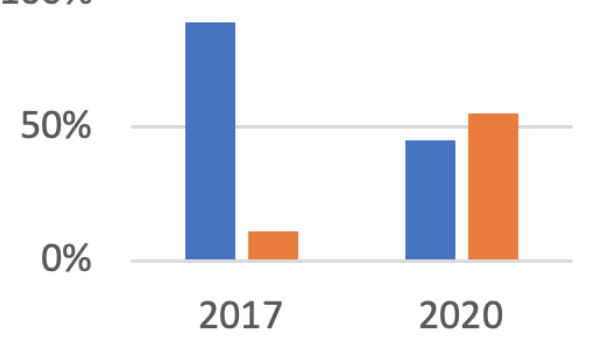

u $<12$ miles $\quad>12$ miles

Fig 4. Changes in the Length of Sailing Time (left) and Distance of Fishing Ground (right) in year 2017 and 2020 [Source: BBRSEKP, 2017 and primary data, 2020] 
In the downstream side, the remote location of Selat Lampa also makes it difficult for fishermen to land their fishes. From their respective locations, the fishermen had to spend a fuel cost of IDR 50,000 up to IDR 500,000 depending on their region of origin, and such fee is not borne by Perindo as the buyer. As they arrive at the landing location, the fishermen also felt that they are not given transparency regarding the price of fish to be sold to Perindo as they tend to be the price taker. The prices offered are often below the market price and payments are not done by "cash and carry" at the time of sale and purchase. Changes in fishing area and the increasing number of ex-trawlers in the territorial sea have also resulted in a reduction of the catches of local fishermen.

There are other problems in the downstream sector related to limited human resources and some infrastructure in the management of the SKPT. The central government still has limitations in the assignment of personnel to implement the SKPT in Natuna Regency. There are also limitations on Reefer Containers and the frequency of sea toll ships from the location to Surabaya or other export ports which are still not optimal. Another problem is the lack of managerial ability in the management of the SKPT. Yet, large capital and good managerial skills are the most important aspects that must be acquired in a resource frontier region (Roeseler \& Azam, 1990). Perindo is currently experiencing difficulties in operating due to the mismatch between the plans and the obtained results. Only $5-10 \%$ of fishermen directly deposit their catch to Perindo; the rest of the catch are sold to other collectors who resell them back to Perindo or to Singapore, Jakarta and Pemangkat markets (Wardono et al, 2020). This results in budgeting constraints for their fisheries business operations. Perindo has provided a lot of loans to fishermen, meanwhile it had also spent some initial capitals given to local fishermen. Perindo is also currently changing its head of business manager, which is seen as a step to revive the company's performance. Perindo's adversity is being taken advantage of by many other large collectors to buy fish from the fishermen. By duplicating facilities owned by Perindo, currently, large collectors are also building mini ice factories for fishermen and their cold storage.

\section{The Social Impacts of Industrialization of Fisheries on the Fishing Community}

The social impact that occurs on a small island is usually a process of change that results from a combination of place identities, contexts, actors, events, as well as local and political dynamics that will affect their lives in the future (Baldacchino, 2005; Conkling, 2007). It affects their future because social happenings to a society will affect their lifestyle, habits, perspective, and so forth. The problems arising from fisheries industrialization of the outer islands have resulted in the emergence of several social impacts on the vulnerable community. The vulnerable community in question is the fishing community, since they are still very dependent on other parties and are not yet empowered in terms of capital ownership, technological capability, and access to markets (Zulham, 2018).

There are at least four transformations identified based on FGD and in-depth interviews, as well as observation and secondary data, including: 1) Community awareness; 2) Cohesion and the formation of social relations between communities; 3) Participation in internal and external decision making; and 4) Equitable distribution of income, quality of life and level of happiness. The first transformation is related to community awareness and social cohesion. The industrialization program established by the government requires community-based institutions as a medium for channeling capital aids and trainings in the framework to realize integrated fisheries. The current formal institutions are made based on directives from the central government and not purely based on the desire of the community. Cooperatives or associations were then born in the fishing community with no awareness of the necessity to form 
groups. It should be noted that Natuna residents have a very solitary culture. This is visible from the shape and capacity of their ships, which can only be boarded by 1-3 people each. The majority of Natuna fishing community also own their own ships and do not work with other people. Several cooperatives or associations do not have the sense of mutual need and benefit, and it results in the existing institutions being inactive; they will resume their activities only when there are activities initiated by the central government. Moreover, the formation of institutions instantly creates jealousy among other society members or groups as there is no mutual trust. For example, the decision to provide aid and training to a certain group will cause envy in other fishing community, which had never happened before. The institutional formation process that has occurred in the Natuna fishing community was not successful, even though various facilities and large funding had been provided. Therefore, the industrialization programs that are built in the community should contain visions, missions, values, rules, and perspectives that can be translated to fishermen's institutions at the community scale; it is not just a matter of building facilities and infrastructure (Jentoft, 2014).

The second transformation is the formation of relations and social cohesion. When an area has fisheries business as one of the livelihoods of their community, then it can be ascertained that a social relation that is very attached to the community have already been established (Miñarro et al, 2016; Turner et al, 2014). The existing social relation in the local Natuna fishing community is strongly tied and has patron-client pattern. However, other actors such as the market or fisheries business actors from outside the region have opened up new relations, both with new players from the central government and new local players arising from SKPT activities. With the opening up of market opportunities and the provision of infrastructure, investors are starting to understand that Natuna is a production source that can be utilized in their business processes.

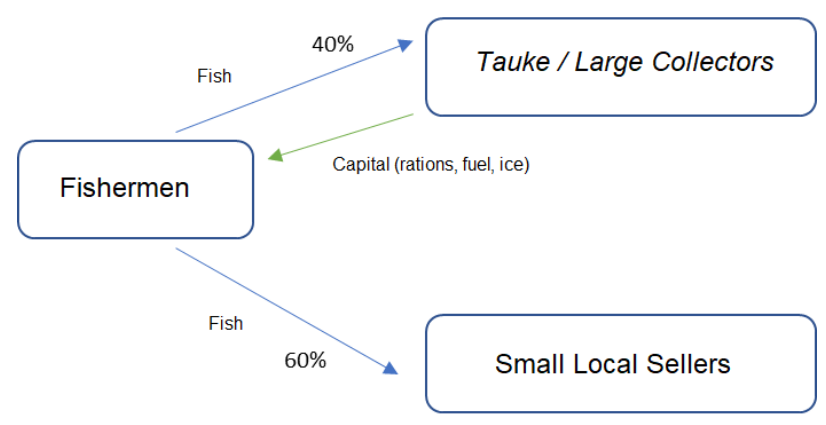

Primary Data, 2020]

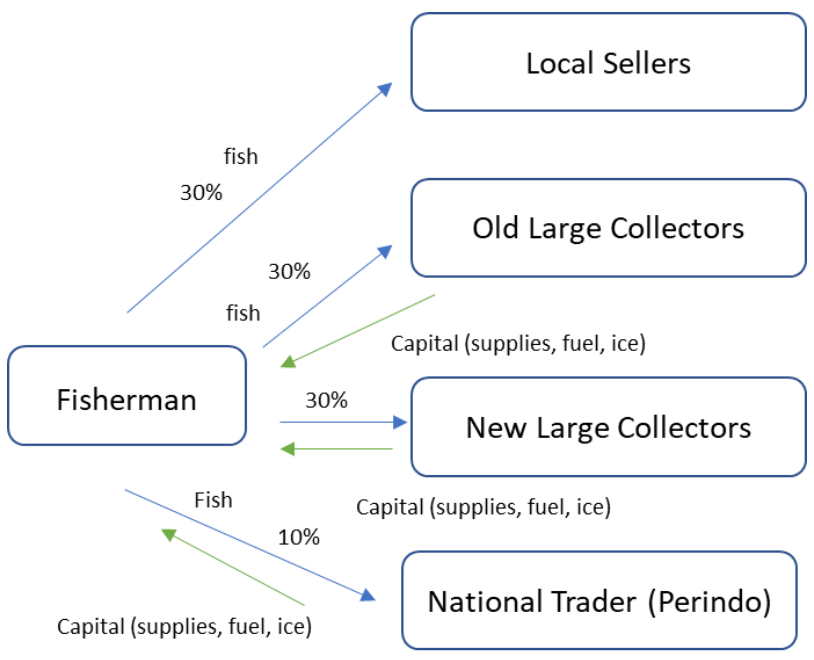

Figure 5 shows a change in relation between fishermen and the buyers, as well as an increase in the level of the fishermen's dependence on the market relation. Based on information gathered during the FGD with the Regencies and Provincial Fisheries Office, prior to the fisheries industrialization (SKPT), the Fishermen's Association has been selling their fish to small local traders $(60 \%)$ with no debt. By the entrance of industry, currently the fishermen are selling more fishes to old wholesalers (30\%) or big traders $(30 \%)$ who have just emerged, by making debt bonds. This may be due to 
demands for more catches or because of the strong competition from migrant fishermen, which makes it necessary for local fishermen to sail further to fish. This confirms the situation faced by fishermen such as in Solomon Islands, Kenya, and Zanzibar, who previously worked on small scales using traditional methods and only catching more fish when prices and markets were good, are now turning to getting more fishes to sell to collectors (Brewer et al., 2009; FAO, 2010; Crona et al., 2010).

On the other hand, industrialization opens up opportunities for encounters between endogenous and exogenous elements from outside the island to form a relation. Such relation motivates several local actors and regional officials to develop the island in accordance with new knowledge and current developments. Furthermore, there is an appearance of a maritime public figure that is currently moving towards the regional head arena and bringing awareness on important fisheries issues. This public figure often becomes a spokesperson that speaks of Natuna's strengths including its sea in a geopolitical context; one of their ideas is that Natuna fishermen must be modern and sovereign in their own territory. Fishermen should be able to be transformed into a promising profession; therefore, the figure had established a workshop that they consider as a place to experiment and obtain information related to fishing and shipping. There are also other local figures, such as the Village Head of Pulau Tiga who is trying to advance the fishermen community by forming a fishermen association. In addition, there are also other local institutions that are trying to develop Natuna's fisheries sector, namely the Natuna Regency Fisheries Service, who explained in their strategy presentation that they are agents for change that must occur in Natuna if they expect their area to advance as a fisheries base (Damhudi, 2020). The problem is that the Fisheries Service currently does not have any authority over the sea; they can only focus on empowering the fishermen. What they are doing is transforming the knowledge of traditional fishermen regarding more modern fishing gear and ships. The transfer of knowledge will happen well when there is trust between the fishermen and their instructor (Sofia, 2015).

The third transformation is community participation, both internally and externally. Internally, the level of participation of fishermen is basically quite good. This is especially the case for fishermen associations or cooperatives that were created by the initiative of the fishermen's figures. As happened in Pulau Tiga, the Village Head took the initiative to form a fishermen association for Pulau Tiga that has been continuously active in holding meetings and activities. These findings were obtained from the results of in-depth interviews. Apart from that, rules are also made clear based on mutual agreements, such as the amount of fees and coordination of fishermen's activities. Meanwhile, participation in forums held by the central government is usually limited to the chairperson or representative of fostered institutions, so it is not evenly distributed.

The fourth transformation is equitable distribution of income and high level of happiness. The local fishermen feel that they have not benefited much from the integrated fisheries industry in Natuna. Based on the interviews with the fishermen of Pulau Tiga Subdistrict, most of them thought that there was no difference in income before and after the establishment of the SKPT. In fact, they are now being disadvantaged by the migration of ex-trawlers to the territorial sea. As a matter of fact, the ex-trawlers' fishing area should have been in the EEZ area, but they migrated to shallower seas due to incompatibilities of their fishing gear. Based on interviews with fishermen of Pulau Sedanau, this has led to several conflicts between local fishermen and migrant fishermen. At night, migrant fishermen often pilfer fishes from the fish aggregating devices installed by local fishermen. Moreover, local fishermen are also often seen to hold demonstrations to reject migrant fishermen (Ogen, 2020). This situation will certainly have a negative impact if not managed early. Conflicts on land use, in this case including the waters, will cause serious problems for the community (Feola et al, 2015). With regard to the fishing areas, especially for fishermen who tend to not go far to sea, decisions 
about where to fish are very much based on the knowledge of such fishermen that was acquired by facing high uncertainty at sea, so it is not an easy thing to change (Mangel and Clark 1983).

\section{Discussion}

\section{Assessing Islanders' Rights in the Context of Fisheries Industrialization}

Industries in small island areas, apparently have some different impacts and consequences. At least Putnam's thought that the social involvement of the community and economic growth with industrialization will have a reciprocal relationship does not seem to entirely happen in the context of fisheries industrialization in the outer islands. This happens because the exogenous power that comes in the form of investment, market and regulation is greater than the social capital accommodated by the government as the decision maker. When development models are provided with a top-down approach or if they are imported from other geographic areas, they will usually find failure and are unsustainable (Turliuc, 2008). The fishing industry focuses more on increasing fish production so that it still fails to consider indigenous social relations in society that have occurred for a long time. Lack of an integrated understanding of social and economic development makes development unsustainable in the long term, by not placing human capacities at the center of social, scientific, and economic change. The issue is not whether economic growth is a necessary development component, The problem is not whether economic growth is a necessary component of development, but to whom this economic growth can benefit (Gomez, 1993)

There are several reasons why social involvement does not occur in the context of industrialization in the case of the outer islands. In agreement with Friedmann (1992, p. 98), the power of local fishing community has been taken away. There are at least 3 types of power capabilities in the fishing community that have been taken away. The first, the social power in the form of access to marine production bases. Currently, many local fishermen have been displaced from their own sea territory, in the sense that their fishing areas are used by other fishermen so that they have to change their fishing locations. This is similar to what Kala (2011) said that the consequences of relocating, referring to fishing locations, will result in the disorganization of informal social networks that are already owned by local communities. The social power taken from the islanders shall lead to several potential conflicts, both vertical and horizontal in nature, and cause income inequality that conflicting with the objectives of the development itself which aims to minimize income inequality. Second is the political power in the form of access by individuals in making decisions, voicing aspirations, and acting as a group. The institutions that have been established in the context of the SKPT were only used as a formality to obtain aid, not a true sense of political power. The last is the psychological resources in the form of awareness of selfpotential. Currently, the increasing number of new players in their sea territory often deepens the fishermen's sense of inferiority. Traditional social networks and norms might discourage the adoption of unfamiliar and unconventional new technologies as Akerlof's (1976) thought. The technological difference makes them feel that they no longer know their sea territory as well as before.

The industrialization of fisheries program has resulted in inequality of power and the loss of some rights held by local fishermen. One of the ways to empower marginalized communities is by giving them social power in the form of access to production bases as well as safe living and working environments for them (Friedmann, 2010). Beside the unbalanced power, this inequality of power leads to local involvement does not occur as described. As illustrated in Figure 6, the 
institutions of the local community have an important role in obtaining and utilizing the power to create development that protects community rights and acts as a bridge between the country and the individuals in a society (Friedmann, 2010; Bahmani, 2016). Local institutions play an important role in bridging external and internal relations. Not only functioning as a bridge, local institutions are also considered to be guarding local wisdoms that are considered to protect vulnerable areas. Additionally, local institutions also allow people in the fisheries industry to get transfer of knowledge on catching, marketing, and processing of fish (Jentoft, 2014). But what often becomes a problem is how can we develop local institutions? In this case, local institutions have not been able to play an optimal role; therefore, it is the duty of the state to ensure the continuous provision of the rights of the islanders or fishermen to ascertain that the local institutions will develop properly during the development process.

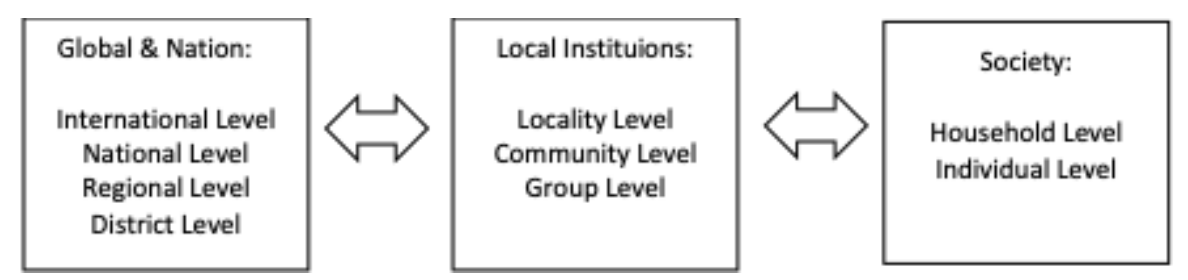

Fig 6. The existence of local institutions in regional development decision-making activities [Source: Adapted from Uphoff (1986, 1992)]

Local institutions can be encouraged by the presence of local and non-local actors as the driving force of local institutionalization in the fishing community. In the Natuna fishing community, local institutions grow better with the existence of a central or strong figure, as the community has a clear role model. Figures in local institutions may encourage the fishermen's capacity building so that they will be able to represent themselves in every decision making. Based on Putnam's thought, the fishing community should not only be encouraged in decision making, but also to feel that they understand their waters the most, such as with regard to what kind of fishing technologies is good to be used, and to own the right to decide what activities may or may not be allowed to be carried out in their waters. Therefore, any development process that will be initiated will also consider the ecological, economic, social and cultural characteristics of the local community.

\section{Conclusion}

This study indicated that, although industrialization in a region may present opportunities through infrastructure and business development, it also has the potential to cause negative impact especially for social life of vulnerable communities in the respective area. The negative social impacts caused by development programs will contribute to the failure of the development itself. From Natuna we learn that the industrialization of fisheries has caused several social impacts such as the emergence of potential conflicts, the fact that institutions are still considered as formality, and the change of patterns of fishermen's activities in terms of economic activities and social life. This impact results in the loss of social strength in the form of access to marine production bases. Local fishermen are driven out of their own sea areas, in the sense that their fishing grounds are used by other fishermen so that they have to change fishing locations. Second, there is no development of political power in the form of individual access to making decisions, voicing aspirations, and acting as a group because the established institution is only used as a formality to get assistance. Finally, fishermen's self-confidence has decreased because they continue to feel unsupported. The increasing number of 
new players in the sea area often adds to the fishermen's sense of inferiority. These changes seem to discourage the local community from supporting the implementation of the government development programs

What can be done to improve the implementation of fisheries industrialization is to understand local knowledge in fishing communities. Decision makers must have an adequate understanding of the behavior of the local community. Fishermen must be given rights to their own sea and the government must protect these rights. By doing so, it is hoped that this industrialization program will not further marginalize fishing communities and fishermen can develop their capacity and participation in program planning and implementation.

\section{Acknowledgments}

The study fieldwork was funded by P3MI ITB research grant for the year 2020 .

\section{References}

Akerlof, G., 1976. The Economics of Caste, and the Rat Race, and Other Woeful Tales, Quarterly Journal of Economics 90:4, 599-617.

Aida, K., Agustang, A.D.M.P., Adam, A. \& Agustang, A. 2020. The Patron-Client Relationship Patterns In Siwa Lima Fishermen Community, Aru Islands District Maluku, Indonesia. International Journal of Scientific \& Technology Research. 6. 74-77.

Abdullah, M.R., Mohd Kamar, K.A., Mohd Nawi, M.N., Tarmizi Haron, A and Arif, M. 2009. Industrialized Building System: A Definition and Concept. Proc. Of ARCOM Conference 2009. Nottingham, UK.

Bahmani, J., 2016. The Role of Civil Society in Development. Journal of Civil \& Legal Sciences. 05. https://doi.org/10.4172/21690170.1000215 .

Baldacchino, G., 2005. The contribution of 'social capital' to economic growth: lessons from island jurisdictions. The Round Table, 94(1), 31-46. https://doi.org/10.1080/00358530500033075.

Baldacchino, G \& Pleijel, C. 2010. European Islands, Development and the Cohesion Policy: A Case Study of Kökar, Åland Islands. Island Studies Journal. 5.

Baldwin, R. and Martin, P. 2004. Agglomeration and Regional Growth. In J. V. Henderson and J. F. Thisse (eds) Handbook of Regional and Urban Economics: Volume 4 Cities and Geography. Elsevier B.V.: Amsterdam, pp. 2671-711.

Bamberger, M. 1986. The Role of Community Participation in Development Planning and Project Management. An EDI Policy Seminar Report no. 13, The World Bank: Washington DC.

BPS Kabupaten Natuna. 2017. Natuna Dalam Angka Tahun 2016. Badan Pusat Statistik Kabupaten Natuna.

BPS Kabupaten Natuna. 2021. Natuna Dalam Angka Tahun 2020. Badan Pusat Statistik Kabupaten Natuna.

Brewer, T. D., Cinner, J. E., Green, A., and Pandolfi, J. M. 2009. Thresholds and multiple scale interaction of environment, resource use, and market proximity on reef fishery resources in the Solomon Islands. Biol. Conserv. 142, 1797-1807.-

https://doi.org/10.1016/j.biocon.2009.03.021.

Burdge, R. J. And Vanclay, F. 1996. Social Impact Assessment: A Contribution to the State of the Art Series, Impact Assessment, Vol. 14, March 1996.

Castles, S., 2001. Studying Social Transformation. International Political Science Review. 22. 13-32.

https://doi.org/10.1177/0192512101221002. 
Ciscel, D., and Heath, J., 2001. "To Market, to Market: Imperial Capitalism's Destruction of Social Capital and the Family." Review of Radical Political Economics 33, no. 4:401-14.

Clark, E., 2009. Island development. In R. Kitchin \& N. Thrift (Eds.) International Encyclopedia of Human Geography, 5 (pp. 607-610). 0xford: Elsevier. https://doi.org/10.1016/B978-008044910-4.00849-X.

Cooke, P., Heindenreich, M. and Braczyk, H. J., 2004. Regional Systems Innovation: The Role of Governance in a Globalized World, 2 edn. Routledge: London.

Conkling, P., 2007. On islanders and Islandness. The Geographical Review, 97(2), 191-201.https://doi.org/10.1111/j.19310846.2007.tb00398.x.

Crona, B., Nyström, M., Folke, C., and Jiddawi, N. (2010). Middlemen, a critical social-ecological link in coastal communities of Kenya and Zanzibar. Mar. Policy 34, 761-771. https://doi.org/10.1016/j.marpol.2010.01.023.

Damhudi, D., 2020. Karakteristik Perikanan Tangkap dan Peran Dinas Perikanan di Kabupaten Natuna. The presentation was delivered on June $20^{\text {th }} 2020$ at FGD online.

Esteves AM., 2008. Evaluating community investments in the mining sector using multi-criteria decision analysis to integrate SIA with business planning. Environmental Impact Assessment Review. 28(4-5):338-348.

FAO, 2010. Small-scale and Artisanal Fisheries. Accessed November $3^{\text {rd }}, 2020$, at http://www.fao.org/fishery/topic/14753/en.

Feola, G., Lerner, A., Jain, M., Montefrio, M.J.F., Nicholas, K.A., 2015. Researching farmer behaviour in climate change adaptation and sustainable agriculture: lessons learned from five case studies. J. Rural Stud. 39.

Friedmann, J., 1966. Regional development policy: a case study of Venezuela. Cambridge, Mass. : M.I.T. Press.

Friedmann, J., 1992. Empowerment: The Politics of Alternative Development. Cambridge Mass.: Blackwell Publisher. Massachusetts.

Friedmann, J., 2010. Rethinking Poverty: Empowerment and Citizen Rights. International Social Science Journal. 48. $161-172$.

https://doi.org/10.1111/j.1468-2451.1996.tb00070.x.

Gomez, D.A.M., 1993. The Social Challenge In Development From Economic To Social Policies. International Development Research Centre: Canada.

Gren, J., 2003. Reaching the Peripheral Regional Growth Centres. European Journal of Spatial Development, 3, pp. 1-22.

Grydehøj, A., \& Hayward, P., 2014. Social and economic effects of spatial distribution in island communities: comparing the Isles of Scilly and Isle of Wight, UK. Journal of Marine and Island Cultures, 3(1), 9-19. https://doi.org/10.1016/j.imic.2014.03.002.

Hilborn, R., 2007. Managing fisheries is managing people: what has been learned? Fish and Fisheries 8:285-296.https://doi.org/10.1111/14672979.2007.00263-2.x.

Jentoft, S., 2004. 'Institutions in Fisheries: What They Are, What They Do, and How They Change'. Marine Policy. 28. 137149. https://doi.org/10.1016/S0308-597X(03)00085-X.

João, E., Vanclay, F., den Broeder, L., 2011. Emphasising enhancement in all forms of impact assessment: introduction to a special issue. Impact Assessment and Project Appraisal.29(3):170-180.

Kala, C. P., 2011. Indigenous Uses and Sustainable Harvesting of Trees by Local People in the Pachmarhi Biosphere Reserve of India. International Journal of Medicinal and Aromatic Plants, 1 (2):153-161.

Kementerian Kelautan Perikanan, 2017. Rantai Pemasaran SKPT Natuna. Accessed November $5^{\text {th }} 2021$ at https://kkp.go.id/SKPT/Natuna/infografis-detail/1870-rantai-pemasaran-skpt-natuna.

KKP Planning Bureau, 2017. Grand Desain Sentra Kelautan dan Perikanan Terpadu. Kementerian Kelautan Perikanan: Jakarta. 
KKP, 2012. Ministerial Decree No. 18 of the General Guidelines Minapolitan. Jakarta.

Kent. G., 1986. The Industrialization of Fisheries. Peasant Studies Vol 13 no 2.

Krugman, P., 1991. Increasing Returns and Economic Geography. Journal of Political Economy, 99, pp. 483-99.

Lewis, J., 2009. An Island Characteristic: Derivative vulnerabilities to indigenous and exogenous hazards. Shima: The International Journal of Research into Island Cultures Volume 3 Number 1.

Mangel, M., and C. W. Clark., 1983. Uncertainty, search, and information in fisheries. Journal of the International Council for the Exploration of the Sea 41:93-103.

Miñarro, S., Navarrete, F., Gabriela, Reuter, H \& van putten, I., 2016. The role of patron-client relations on the fishing behaviour of artisanal fishermen in the Spermonde Archipelago (Indonesia). Marine Policy. 69. 73-83. https://doi.org/10.1016/j.marpol.2016.04.006.

Norris, P., 2001. Making Democracies Work: Social Capital and Civic Engagement in 47 Societies. British Journal of Political Science. 35.

Ogen., 2020. Nelayan Demo Tolak Kapal Cantrang di Natuna, accessed at https://kepri.antaranews.com/berita/66114/nelayan-demo-tolakkapal-cantrang-di-natuna.

O'Sullivan, A. Sheffrin, S.M., 2003. Economics: Principles in Action Upper Saddle River, New Jersey 07458: Pearson Practice Hall 472p.ISBN 013-0630853-3.OCLC 50237774.

Persoon, G \& Simarmata, R. (2015). Undoing 'marginality': The islands of the Mahakam Delta, East Kalimantan (Indonesia). Journal of Marine and Island Cultures. 19. https://doi.org/10.1016/j.imic.2014.11.002.

Priyarsono, DS. 2017. Membangun dari Pinggiran: Tinjauan dari Perspektif Ilmu Ekonomi Regional. Journal of Regional and Rural Development Planning February, 1 (1): 42-52.

Putnam, R.D.. 1993. Making Democracy Work: Civic Traditions in Modern Italy.Princeton, NJ: Princeton University Press.

Putnam, R.D., 2000. Bowling Alone: The Collapse and Revival of American Community. New York: Simon and Schuster.

Roeseler, W., \& Azam, A., 1990. Resource frontier regions : Strategic development planning and management. Ekistics, 57(344/345), 319-331. Retrieved October $28^{\text {th }}, 2020$, from http://www.jstor.org/stable/43622187.

Salim W. \& Negara, S.D., 2019. Infrastructure Development Under Jokowi Administration: Progress, Challenges and Policies. Journal of Southeast Asian Economies 35(3): 386-401, 2018.

Selwyn, R., 2011. Development policy in small countries. London: Routledge.

Schuerkens, U (ed.) 2004 Global Forces and Local Lifeworlds: Social Transformations. Monograph book series: Sage Studies in International Sociology. London, Thousand Oaks, CA and New Delhi: Sage.

Smith, C, Burke, H and Ward, G K., 2000. “Globalisation and Indigenous Peoples: Threat or Empowerment?" in G Ward and C Smith St Leonards (eds.), In Indigenous Cultures in an Interconnected World. N.S.W.: Allen \& Unwin.

Sobel, J., 2002. Can We Trust Social Capital?. Journal of Economic Literature 40, 139-154.

Sofia, L.A., 2015. Fishermen's perception and participation in fisheries resources conservation of Batungap Swamp in Tapin Regency, South Kalimantan, Indonesia, AACL Bioflux, 2017, Volume 10, Issue 6.

Sofield, T. H. B., 2003. Empowerment for sustainable tourism development. Amsterdam: Pergamon.

Stewart, A.M., 1994. Empowering People. Pitman Publishing, London.

Sutikno, S, MSW (2017). The Impact of Industrialization on The Regional Economic Development and Community Welfare. Jurnal IImu Ekonomi Volume 6 (2), October 2017 P-ISSN: 2087-2046; E-ISSN: 2476-9223 Page 231-246. 
Turliuc, C., 2008. 'Modernization and/or Westernization in Romania during the Late $19^{\text {th }}$ Century and the Early 20th Century', 2008, Transylvanian Review, vol. 17, no. 1, pp. 3-12.

Turner, R. A., N. V. C. Polunin, and S. M. Stead., 2014. Social relations and fishers' behavior: exploring the links between information flow and fishing success in the Northumberland lobster fishery. Ecology and Society 19(2): 38. https://doi.org/10.5751/ES-06456-190238.

Thanoon, W.A., WahOeng, L., Kadir,. Jafaar, M.S and Salit, M.S., 2003. The Essential Characteristics of Industrialized Building System, Proc. Of International Conference on Industrialized Building Systems, Kuala Lumpur, Malaysia, pp 283-292.

United Nation Industrial Development Organization. 2020. What Industrialization Means For Well-Being - And Why It Matters. Vienna.

Uphoff, N., 1986. Local Institutional Development: An Analytical Sourcebook, with Cases. Kumarian Press, West Hartford, CN.

Uphoff, N.. 1992. Local Institutions And Participation For Sustainable Development. IIED Gatekeeper Series.

Vanclay, F., 2003. International Principles for Social Impact Assessment: their evolution. Impact Assessment and Project Appraisal - Impact Assess Proj Apprais. 21. 3-4. https://doi.org/10.3152/147154603781766464.

Vanclay F., 2015. The potential application of qualitative evaluation methods in European regional development: Reflections on the use of Performance Story Reporting in Australian natural resource management. Regional Studies 49(8):1326-1339.

Wardono, B., Muhartono, R., Apriliani, T Hikmah, \& Zulham, A., 2020. Traditional Fisheries Supply Chain Management in The Border Area: The Natuna Islands, Indonesia. E3S Web of Conferences 147, https://doi.org/10.1051/e3sconf/202014702009.

Zulham, A., 2018. Penilaian Sosial Dalam Membangun Entitas Bisnis Perikanan Pada SKPT Selat Lampa, Natuna. Jurnal Kebijakan Sosial Ekonomi Kelautan dan Perikanan. Vol 8 No 1 Page 77-90. 